\title{
Budaya masyarakat dalam membangun rumah vernakular di Pesisir Pantai
}

\section{Society's culture in building vernacular house in coastal area}

\author{
Wilhelmus Hary Susilo \\ Program Studi Teknik Arsitektur, Universitas Persada Indonesia. \\ Jalan Diponegoro No. 74, Jakarta Pusat, Indonesia.Telepon: 087878305059. \\ E-mail: harry_susilo@hotmail.com / hasusilo@yahoo.com
}

\begin{abstract}
Absract
Indonesia is a country with various cultural heritages, amongst of them is the way people construct their house. Understanding culture of society in buliding house will enable people to maintain tradition and distinctness of each region. The purpose of this research is to describe the way people build houses typical to west coast area in Sumatra. Method uses in this research include (1) preparatory team, (2) assessment reference of vernacular house, (3) preliminary survey, (4) field observation, (5) interview, (6) measurement: to be proceed manually by the use of a measuring manual; conducted towards an architecture object, (7) micro study documentation. The data analysis covered six activities: (1) documenting the results of openended interviews; (2) portrayal of the measurement results; (3) aspect analysis: scatter pattern, building pattern, details of architecture, materials and structural proportions; (4) findings of unique elements building; (5) comparation to concept of new vernacular architecture; (6) finding the potential for vernacular architecture parts of the coastal part of Indonesia. Finally a new vernacular model house architecture can be obtained as a dynamic model used by people in building their houses.
\end{abstract}

Keywords: house building culture, dynamic model, cultural variation, coastal area

\begin{abstract}
Abstrak
Indonesia memiliki begitu banyak khasanah kultural yang menjadi warisan budaya salah satunya adalah membangun rumah tinggalnya. Memahami budaya masyarakat tertentu dalam membangun rumah akan dapat mempertahankan tradisi dan keunikan dari setiap daerah. Tujuan penelitian ini adalah untuk mendeskripsikan bangunan rumah khas di pesisir pantai Sumatera Barat. Metode penelitian ini menggunakan observasi meliputi: (1) persiapan tim, (2) kajian referensi rumah vernakular Indonesia, (3) survei awal, (4) observasi lapangan, (5) wawancara, (6) pengukuran: dilakukan secara manual dengan menggunakan alat pengukur manual dan dilakukan terhadap objek riset arsitektur yang telah ditetapkan, (7) dokumentasi studi mikro di Padang Sumatra Barat. Langkah-langkah dalam tahap analisis data meliputi enam kegiatan, yaitu: (1) mendokumentasikan hasil wawancara open-ended; (2) penggambaran kembali hasil pengukuran di lapangan; (3) analisis hasil riset, meliputi aspek-aspek: pola sebaran, pola membangun, detail-detail arsitektur, proporsiproporsi bahan dan struktural; (4) temuan unsur-unsur bangunan yang unik; (5) membandingkan dengan konsep new vernakular architecture; (6) potensi arsitektur vernakular pesisir pantai di Indonesia, dengan melakukan dokumentasi pada bangunan rumah pesisir pantai di dua lokasi berbeda, yaitu di Sumatra Barat, sebagai prioritas kajian, dan lokasi kedua di wilayah Sulawesi Selatan sebagai variabel kajian kontrol. Kemudian model arsitektur rumah vernakular baru sebagai hasil penelitian yang didapat adalah suatu model dinamik variabel-variabel budaya masyarakat dalam membangun rumahnya.
\end{abstract}

Kata kunci: budaya membangun rumah, model dinamik, variasi budaya, area pantai

\section{Pendahuluan}

Penggalian akar tradisi dilakukan melalui adanya penelitian yang tidak sekedar merekam penampilan fisik dan visualnya, melainkan juga dengan sistem nilai dan sistem sosial masyarakat pendukungnya pada ruang dan waktu tertentu (Budihardjo 1997:33). Kajian ini berpusat pada permasalahan yang dihadapi untuk dapat melestarikan budaya membangun yang berkelanjutan pada areal kawasan pesisir pantai, yang memiliki keunikan tertentu sehingga akan dapat menemukan suatu model budaya membangun rumah vernakular di Padang Sumatra Barat. 
Provinsi Sumatera Barat dikenal juga dengan sebutan Ranah Minang atau Minangkabau. Ibukotanya adalah Kota Padang. Banyak orang beranggapan bahwa arsitektur tradisional di wilayah Padang dan sekitarnya adalah bangunan khas Minangkabau yang beratap gonjong. Namun persepsi itu berubah total jika kita menelusuri kampung-kampung dan pedesaan di sekitar Kota Padang. Memang di sana banyak juga ditemukan rumah gadang hanya saja tidak ada yang beratap Gonjong. Padang Pariaman ternyata menyimpan kekhasan arsitektur tersendiri, penulis menyebutnya sebagai arsitektur vernakular Padang Pariaman, yang memiliki kekhasannya sendiri dan jauh berbeda dengan arsitektur tradisional Minangkabau.

Saat ini masyarakat Padang Pariaman, khususnya di Kota Padang banyak yang tinggal dekat dengan pantai, bahkan kawasan Pantai Padang dikenal sebagai pemukiman tepi pantai terpadat di Indonesia. Sebenarnya pada jaman dahulu masyarakat Padang Pariaman tidak tinggal di tepi pantai. Ada syair yang mengatakan "jika takut dilamun ombak, jangan tinggal di pantai". Hanya pendatang yang tinggal di pantai. Pergeseran tersebut terjadi sekitar abad ke-16 ketika Padang Pariaman menjadi kota pelabuhan yang berkembang pesat. Masyarakat Padang Pariaman mulai banyak yang tinggal di tepi pantai dan berbaur dengan pendatang.

Di Padang Pariaman banyak ditemukan rumah gadang. Seperti halnya di Minangkabau, fungsi dan maknanya kurang lebih sama, yaitu berarti rumah besar atau rumah yang menjadi pusat pertemuan keluarga besar. Di Padang Pariaman rumah gadang juga merupakan tempat pertemuan adat dari satu suku. Hirarkinya adalah, satu ibu berhimpun dengan yang lain menjadi satu kaum, dan selanjutnya menjadi satu suku. Secara arsitektural rumah gadang di Padang Pariaman sangat berbeda dengan Minangkabau, baik dari bentuk bangunan dan struktur konstruksi, maupun tata ruang dalamnya. Atapnya pun tidak menggunakan atap gonjong. Arsitekturnya justru banyak dipengaruhi oleh Aceh dan Melayu. Secara sekilas bentuknya tidak jauh berbeda dengan arsitektur tradisional di daerah-daerah sepanjang pantai barat Sumatera mulai dari Tapak Tuan di Aceh hingga Bengkulu.

Richardson (2001) mengidentifikasi bangunan-bangunan lokal dan menggambarkan perhatian yang khusus untuk dapat merefleksikan dengan cara inspirasi melalui analogi bangunan.

"It instead describe their intention to reflect by "analogous inspiration" the characteristics of local buildings, their scale in particular, whether they have chosen to concentrate on the use of materials, the landscape, the local culture or even no more than the idea of continuity with the past" (Richardson 2001:6).

Selanjutnya untuk dapat membentuk karakteristik dan keunikan bangunan dapat melalui beberapa aspek arsitektural meliputi; proporsi-proporsi material dan struktur konstruksi, skala dan irama mempengaruhi terbentuknya karakteritik pada suatu bangunan (Ching 1984). Menurut Sutanto (2001) dalam Purwanto dan Gayatri (2007), arsitektur vernakular merupakan transformasi dari situasi kultur homogen ke situasi yang lebih heterogen dan berusaha sebisa mungkin menghadirkan citra, bayang-bayang realitas arsitektur tradisional dan memiliki kepekaan secara teknis, sosial dan cultural, sedangkan menurut Rapoport (1969) dalam Purwanto \& Gayatri (2007) yang menyoroti dari sisi proses, vernakular salah satu proses yang berdasarkan pada model dan variasi. Aspek yang diperhatikan berdasarkan ide-ide yang sangat dimengerti dalam masyarakatnya dan perubahan kecil yang mungkin terjadi tetap dalam suatu kesepakatan bersama dalam lingkungan masyarakat tesebut. Selanjutnya Rapoport (1969:72 dalam Nuryanto \& Machpudin 2008) menyatakan bahwa arsitektur vernakular adalah permukiman yang merupakan perwujudan hasil karya manusia secara turun-temurun dari seluruh lapisan masyarakat dalam batas-batas teritorial tertentu. Suatu bangunan pada wilayah tertentu akan memiliki karakteristik yang unik, begitu pula bangunan-bangunan perumahan yang terletak di pesisir pantai akan memiliki karakteristik yang unik.

Di Indonesia masih banyak terdapat sebaran bangunan-bangunan rumah tinggal vernakular yang belum banyak diteliti oleh peneliti, yang berhubungan dengan lingkup masyarakat, budaya, dan arsitektur. Potensi dari konsep-konsep serta keberadaan bangunan vernakular diyakini memiliki keilmuan yang berhubungan dengan bidang arsitektural bangunan rumah vernakular panggung memiliki karakteristik yang sangat unik. Bangunan rumah vernakular diyakini sangat memikirkan 
sistem pembangunan yang berkelanjutan dan memperhatikan aspek sosial, budaya dan lingkungan. Potensi pengembangan konsep vernakular baru akan dapat menjadikan bangunan memiliki jati diri arsitektur Indonesia.

\section{Metode Penelitian}

Kajian penelitian ini menggunakan pendekatan studi mikro dengan kasus di Padang, Sumatra Barat. Langkah-langkah observasi meliputi: (1) persiapan tim: penyusunan tim riset arsitektur. Pembagian tugas dan rancangan aktivitas dibuat dalam suatu jadwal pelaksanaan riset; (2) kajian referensi rumah vernakular Indonesia: kajian referensi dilakukan sebagai landasan riset empiris yang dilakukan; (3) survei awal: dilakukan oleh dua surveyor arsitektur untuk survei operasional pendahuluan, yang bertujuan memasukan proses perizinan dan menghubungi perguruan tinggi setempat dalam upaya pencarian informasi awal; (4) observasi lapangan: dilakukan oleh seluruh peserta riset arsitektur dalam upaya pencarian data keberadaan rumah- rumah vernakular, dengan langkah awalnya mencari informasi pada jurusan arsitektur salah satu perguruan tinggi setempat. Selanjutnya menuju lokasi-lokasi yang diarahkan, yang didapat dari informasi awal; (5) wawancara: proses wawancara dilakukan terhadap penduduk setempat, dimana rumah vernakular yang didapat menjadi objek riset arsitektur; (6) pengukuran: dilakukan secara manual dengan menggunakan alat pengukur manual dan dilakukan terhadap objek riset arsitektur yang telah ditetapkan; (7) dokumentasi berupa foto dan sketsa: untuk mendukung pencarian data yang lebih lengkap, dilakukan proses dokumentasi dengan foto kamera digital dan juga melakukan sketsa untuk detail-detail arsitektural dan detail-detail struktur yang unik.

Tahap analisis: langkah-langkah dalam tahap analisis data hasil observasi lapangan secara langsung meliputi enam kegiatan, yaitu: (1) mendokumentasikan hasil wawancara open-ended; (2) penggambaran kembali hasil pengukuran di lapangan; (3) analisis hasil riset, meliputi aspek-aspek: pola sebaran, pola membangun, detail-detail arsitektur, proporsi-proporsi bahan dan struktural; (4) temuan unsur-unsur bangunan yang unik; (5) membandingkan dengan konsep new vernacular architecture; (6) potensi arsitektur vernakular pesisir pantai di Indonesia, dengan melakukan dokumentasi pada bangunan rumah pesisir pantai di dua lokasi berbeda, yaitu di Sumatra Barat, sebagai prioritas kajian, dan lokasi kedua di wilayah Sulawesi Selatan sebagai variabel kajian kontrol; (7) model arsitektur rumah vernakular baru pesisir pantai di Indonesia.

\section{Hasil Penelitian}

\section{Potensi arsitektur vernakular rumah gadang di Padang Pariaman, Sumatra Barat}

Pada masyarakat Minangkabau, Padang Pariaman dianggap sebagai daerah "rantau", yang disebut juga sebagai daerah pesisir. Hal ini dapat dipahami karena cakupan wilayah Minangkabau adalah di dataran tinggi sepanjang pegunungan bagian tengah Sumatera Barat, dengan pusatnya di Batu Sangkar. Namun demikian, masyarakat Padang Pariaman secara adat dan hubungan sosial masih kuat dipengaruhi oleh Minangkabau, meskipun ada juga hal-hal pokok dalam adat Minangkabau yang lebih terbuka, misalnya berkaitan dengan garis keturunan, mereka menerapkan matrilineal sekaligus patrilineal. Garis keturunan matrilineal hanya dipakai sebatas ikatan adat (tidak berdampak pada pembagian harta waris), sedangkan patrilineal sangat penting bagi keberadaan garis keturunan karena berkaitan dengan kedudukan sosial (misalnya masih dipakai nama Bagindo dan Sidin) dan peranan penting dalam fungsi-fungsi tertentu dalam masyarakat adat (misalnya keturunan Datuk atau Pandito).

\section{Atap rumah gadang}

Rumah Padang Pariaman biasa disebut sebagai rumah pesisiran Padang, berbentuk persegi panjang seperti halnya rumah Minangkabau. Atapnya secara umum berbentuk pelana dengan bubungan yang melengkung sedikit dan penutup sisi atap. Atap demikian disebut "gunting pedati" (gunting atau potongan atau gaya), karena mirip dengan atap pedati. Namun secara umum, bentuk demikian 
mirip dengan rumah Melayu dan Bengkulu. Rumah Padang Pariaman biasanya menggunakan ukiran-ukiran Aceh dan sedikit Melayu. Saat ini ditemukan juga banyak variasi atap misalnya "gunting Betawi" (limasan), atap pelana bertumpuk seperti rumah Aceh namun dengan pintu masuk tegak lurus dengan bubungan, serta atap "gunting Kaliyan" seperti rumah Tapanuli, yaitu bagian atas atap pelana dipadukan dengan bagian bawahnya atap limasan.

Arsitektur rumah Padang Pariaman menunjukkan keterbukaan daerah pesisir. Bentuknya merupakan sintesa dari berbagai pengaruh dan penyesuaian terhadap iklim pantai yang lebih panas, mungkin dapat dikatakan sebagai transformasi arsitektur Minangkabau yang mendapat pengaruh kuat dari arsitektur Aceh dan Melayu, khususnya di daerah pesisirnya. Dalam perkembangannya tidak luput juga dari pengaruh Bengkulu, Tapanuli Selatan, Cina, Belanda (istilah atap gunting Betawi diduga dibawa Belanda).

\section{Transformasi bentuk}

Sampai saat ini transformasi tersebut masih terus berlangsung, misalnya pada rumah-rumah diperkotaan yang menyesuaikan diri dengan keterbatasan lahan (bentuk kapling). Penyesuian tersebut nampak pada arah hadap bangunan terhadap jalan, yaitu memanjang ke belakang. Tata ruangnya mirip dengan rumah Minangkabau, yaitu pembagian ruang berdasarkan jajaran kolom pada arah memanjangnya. Perbedaan paling mencolok adalah adanya serambi yang disebut sebagai langkan (dari bahasa Cina) atau beranda. Pagar beranda biasanya dibentuk secara khusus seperti halnya rumah Melayu, dengan ketinggian disesuaikan dengan tinggi bahu orang yang sedang duduk. Keberadaan beranda menunjukkan bahwa ada penyesuaian terhadap iklim pantai yang panas dan hubungan sosial masyarakat pesisir yang lebih terbuka. Untuk mencapai beranda dibuat tangga tepat di tengahnya. Bentuknya variatif sekali, umumnya menggunakan kayu, tetapi ada juga yang menggunakan bata plesteran dengan bentuk melengkung dan diberi atap.

Ada dua pintu masuk ke dalam rumah, yaitu dari arah beranda sebagai pintu utama (untuk tamu dan laki-laki) terletak di bagian tengah berhadapan langsung dengan tangga, dan bagian belakang menuju dapur atau ruang tengah. Pada ruang dalamnya, seperti halnya rumah Minangkabau, menggunakan juga istilah 'ruang tepi' dan 'ruang tengah', bilik berada di sisi kiri biasanya hanya ada dua (berbeda dengan rumah Minangkabau yang biliknya di bagian belakang setelah ruang tengah). Pada bagian belakang kadangkala dibuat bangunan tambahan berupa dapur yang dihubungkan dengan jembatan. Secara khusus di beranda kadangkala ada bilik yang disebut sebagai 'kamar spend' (pengaruh Belanda) yang digunakan sebagai kamar untuk anak lelaki atau kantor (rumah di perkotaan).

Rumah Padang Pariaman banyak yang menggunakan kayu kelapa sebagai konstruksi utama. Teknologi seperti ini tidak ada pada arsitektur tradisional Minangkabau. Tiang-tiang bangunan dibuat tegak dari batang pohon yang tinggi. Terkadang tiang rumah tidak lurus karena batang pohon yang digunakan ada juga yang bengkok atau melengkung. Atapnya dahulu menggunakan rumbia (di Minangkabau: alang-alang), sekarang banyak yang menggunakan seng.

\section{Sebaran rumah vernakular pesisir pantai Sumatra Barat}

Keberadaan rumah Pesisiran Padang, saat ini mulai banyak berkurang. Penghancuran besar-besaran terjadi pada saat perang PRRI, terutama rumah-rumah yang berada di sekitar pantai Pariaman, banyak yang dibakar dan saat ini hanya tersisa sedikit, terutama di sekitar KOTIF Pariaman. Berdasarkan pengamatan justru banyak ditemukan di beberapa tempat di Kota Padang. Namun akibat perkembangan kota, sebenarnya banyak juga rumah tua dari kayu seperti ini yang dihancurkan atau berubah fungsinya. Ada beberapa rumah yang nampaknya masih menunjukkan keasliannya sejak dahulu, tetapi sebagian lain yang tersisa kondisinya sangat memprihatinkan dan berubah bentuknya karena penambahan bangunan yang tidak mengikuti struktur rumah aslinya. 
Beberapa tempat yang masih menyisakan rumah Padang Pariaman adalah wilayah Kota Padang seperti Sungai Limau, Lohbalon, Sicincin, Kampung Perak, Sakaliek Hulu (wilayah pedalaman dengan masyarakat petani sawah dan masih memegang adat satu Suku) dan Sakaliek Ilir (masyarakatnya rata-rata saudagar atau pelaut), Sunur (dahulunya merupakan pusat Kota Pariaman) dan Sigadondong, Sikapak, Ulakan Naras, Sintuk, Air Bangis, Kali Bangih dan Alang lawas. Bahkan di Lubuk Binturun, dan Koto Tuo masih ditemukan beberapa rumah gadang yang masih dalam kondisi terawat. Sedangkan di sekitar Kampong Air Dingin ada dua rumah yang masih bagus kondisinya dan satu rumah yang tinggal menyisakan kerangkanya.

\section{Kajian mikro}

\section{Situasi lingkungan dari rumah vernakular objek riset}

Kawasan perumahan vernakular memiliki kondisi jalan yang baik dan vegetasi yang hijau (Gambar 1). Bangunan rumah tinggal vernakular, rumah panggung dengan atap pedati dipilih menjadi objek penelitian (Gambar 2). Tampak depan bangunan yang masih terjaga dengan baik, elemen bangunan dengan menggunakan kayu menghasilkan tekstur yang bersahabat dan berkesan alami. Umpak batu, kolom kayu dan balok kayu lantai. Umpak terbuat dari elemen batu kali, sedangkan kolom menggunkan kayu merah yang sangat kuat dan pertemuan dengan balok lantai hanya menggunakan pasak kayu yang terbuat dari jenis pohon kayu merah yang sangat kuat yang tumbuh di sekitar lingkungan. Detail sambungan kayu sederhana (Gambar 3) juga dipakai pada sambungan balok lantai dengan handrailing pada teras depan dan ruang tidur utama. Tekstur lantai kayu yang diekspos menimbulkan kesan alami yang kuat, dengan pola lantai memanjang dan membujur dipadukan jadi satu (Gambar 4). Pintu kayu dua daun (Gambar 5) didesain dengan pola geometri yang cukup unik yaitu dengan pola a-b-a yang digabung garis miring membentuk huruf (V), dan di atas daun pintu terdapat lubang angin yang memungkinkan ventilasi angin secara silang serta pola kayu horisontal sebagai gantungan kain penutup pintu menuju kamar, sehingga tercipta faktor privasi yang baik. Konsol kayu (Gambar 6) dengan menggunakan sambungan kayu sederhana yang cukup kuat menopang struktur atap seng di atasnya, dengan sedikit ornamen sehingga menimbulkan kesan estetis sederhana, karena menyatu dengan srtuktur kayu utamanya.

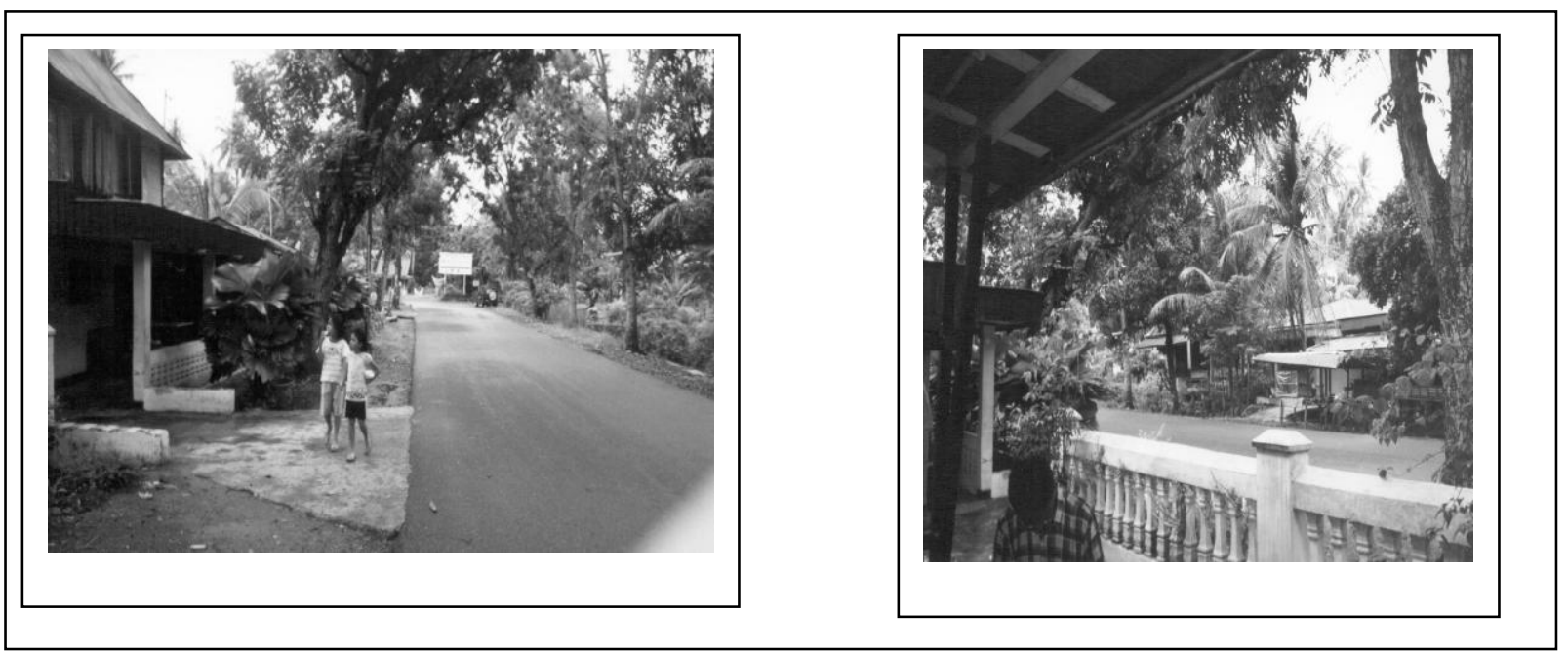

\section{Gambar 1.}

Kawasan rumah yang masih terjaga kondisi vegetasinya 


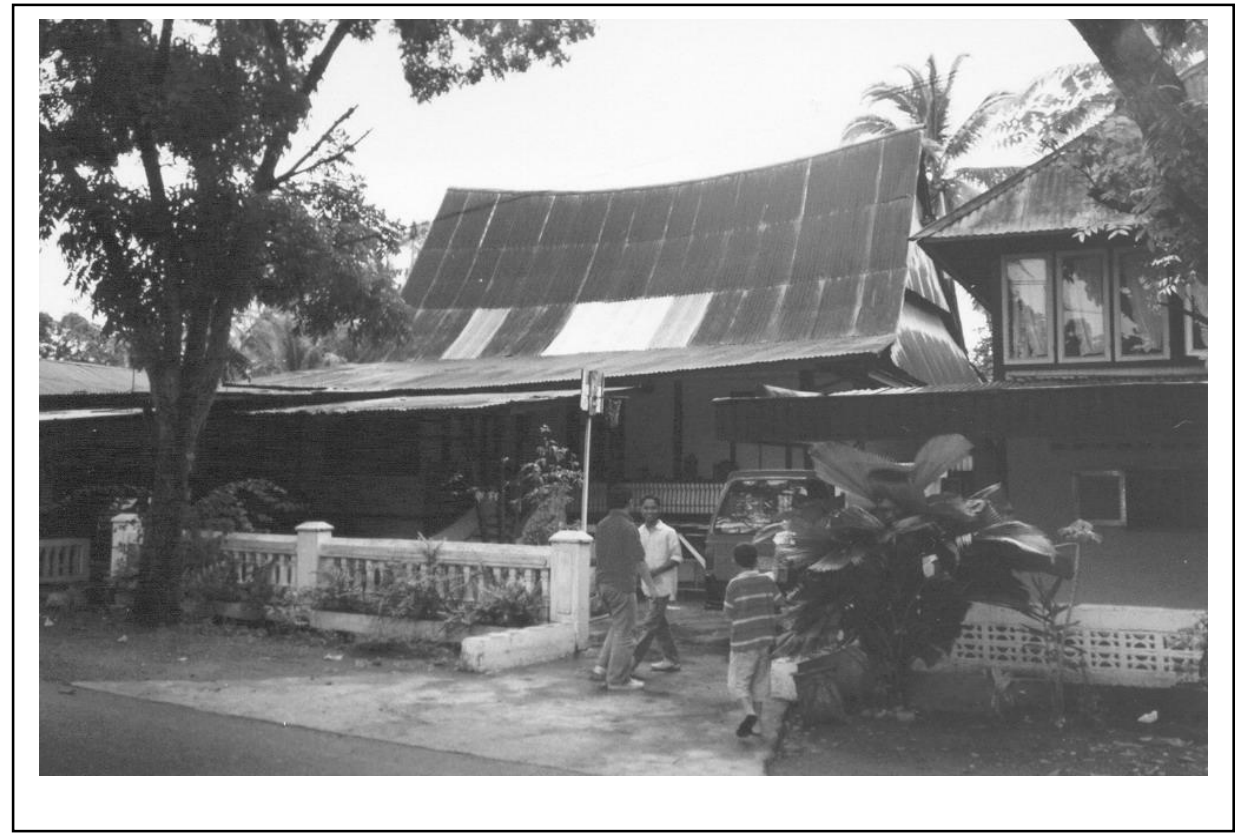

Gambar 2.

Bangunan rumah panggung objek penelitian

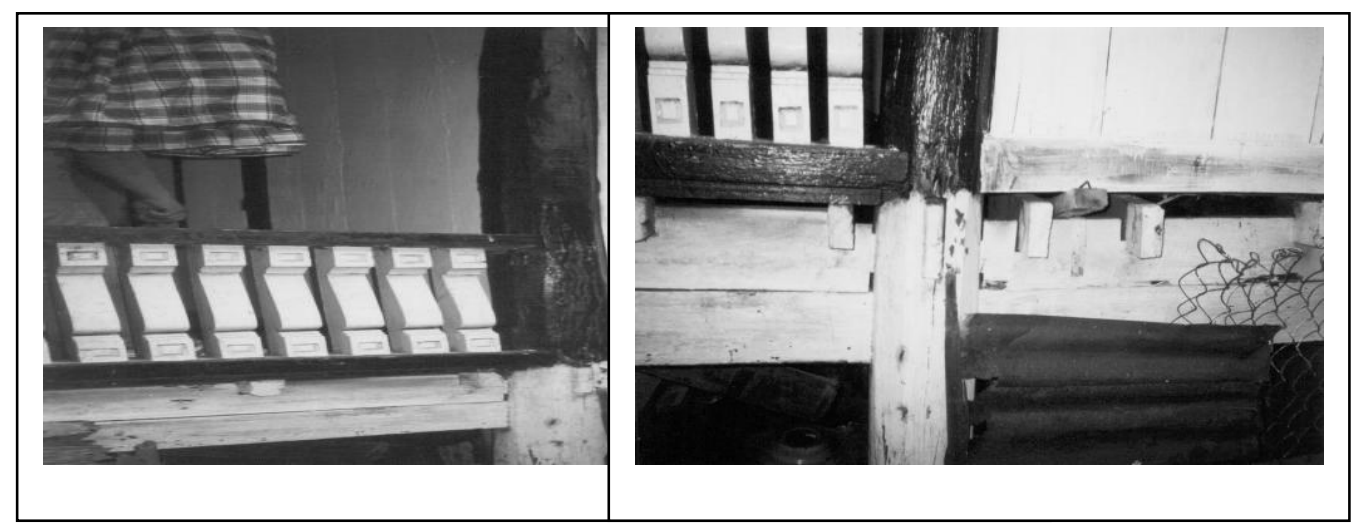

Gambar 3.

Detail sambungan kayu sederhana

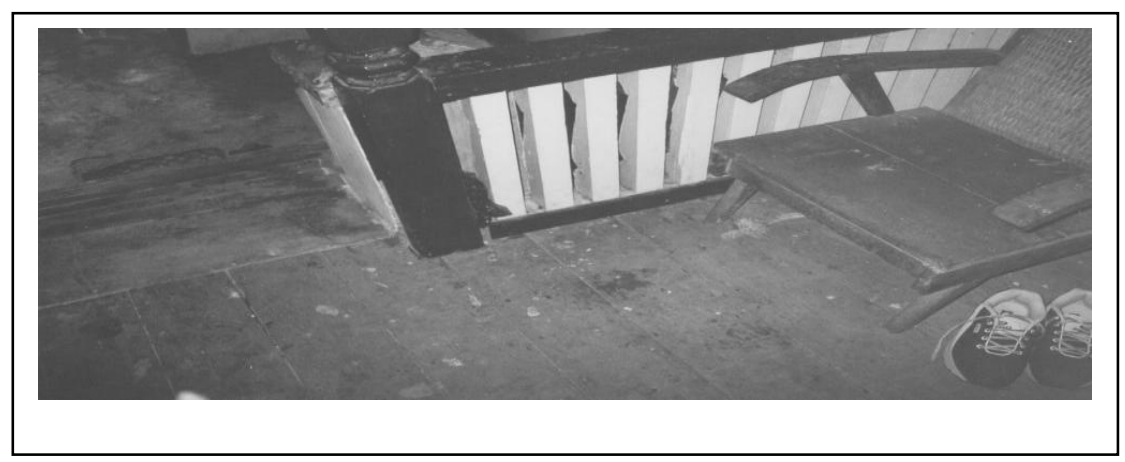

Gambar 4.

Detail lantai kayu dengan pola searah 


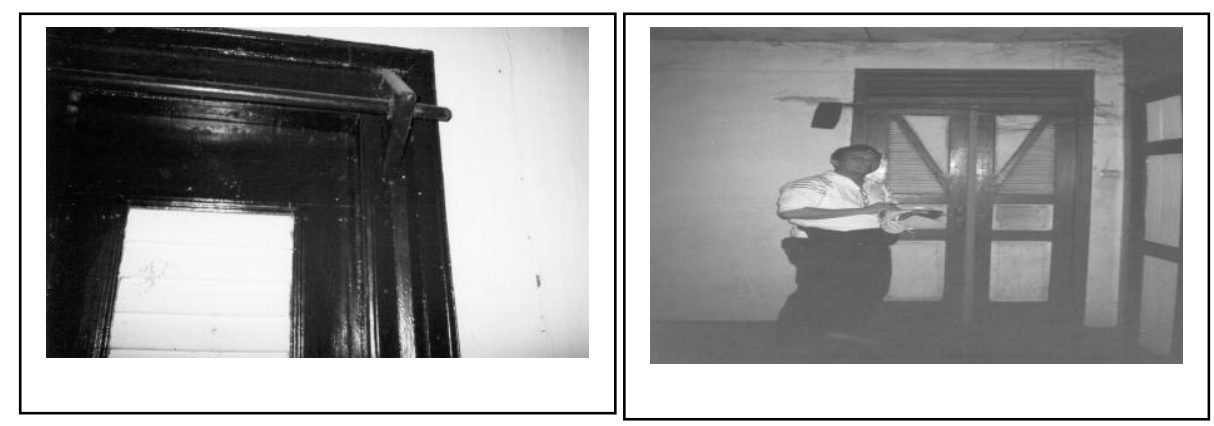

Gambar 5.

Pintu kayu dua daun

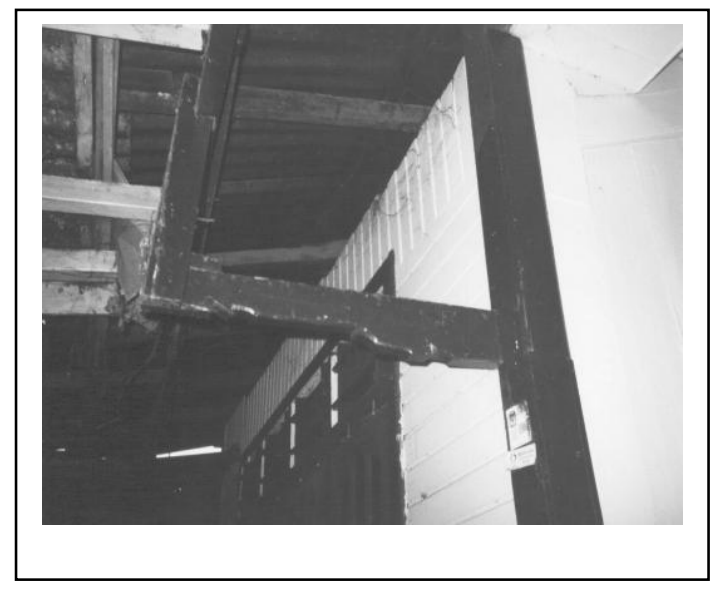

Gambar 6.

Konsol kayu

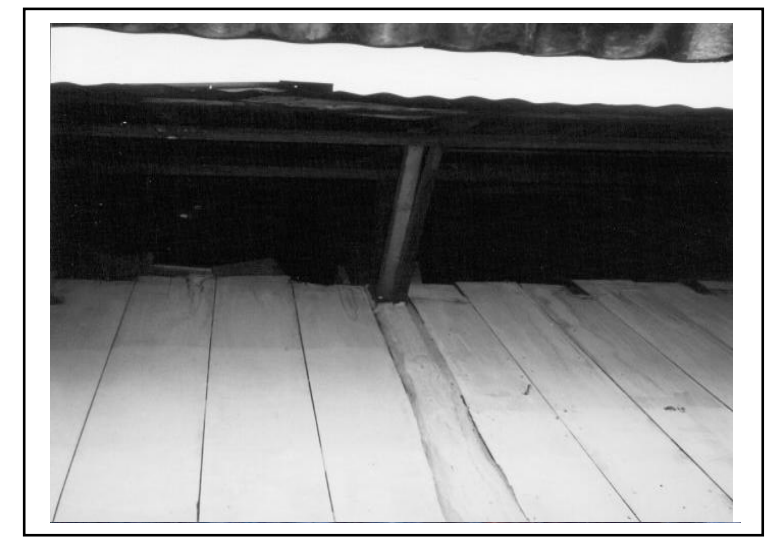

Gambar 7. Dinding kayu

Dinding bangunan rumah dari papan kayu yang dipasang arah vertikal (Gambar 7). Pola tekstur vertikal dari dinding papan yang tersusun secara vertikal menghasilkan pola grid vertikal yang berkesan meninggi dan menghasilkan irama garis vertikal yang teratur.

\section{Rumah vernakular panggung yang merespon iklim lokal}

Kenyamanan termal merupakan masalah yang cukup spesifik pada iklim dengan tingkat kelembaban yang sangat tinggi, seperti di daerah tropis lembab. Menurut Defiana (2002) sudah banyak dilakukan untuk menangani kondisi iklim lokal yang digunakan untuk memecahkan masalah kelembaban udara yang berdampak pada kenyamanan thermal di rumah vernakular. Perancangan rumah vernakular yang ada telah memperhatikan dan merespon kondisi iklim lokal untuk dapat menciptakan kenyaman termal pada ruang dalam. Dengan mempergunakan simulasi komputer (program ARCHIPACK), kajian dilakukan pada rumah arsitektur panggung Nias Utara. Aspek yang diperhatikan meliputi: (1) desain bangunan rumah panggung; (2) pola aktivitas pengguna; (3) pemakaian material bangunan. Evaluasi dari sistem perancangan bangunan dan pemiliham material pada rumah panggung Nias Utara menunjukkan strategi desain untuk pemecahan masalah iklim lokal dan mendapatkan tingkat kenyamanan termal yang baik bagi hunian. Untuk itu evaluasi pada strategi perancangan terdiri dari: (1) bentuk masa yang mengurangi bidang bukaan untuk mereduksi radiasi; (2) pemilihan material yang ramah lingkungan; (3) memperhatikan tingkat dan pola aktivitas; (4) optimalisasi pola sirkulasi udara silang yang baik. Selanjutnya menurut Purwanto dan Gayatri (2007) dalam penelitian Arsitektur vernakular Nabire, menyatakan adanya keterkaitan antara makrokosmos (lingkungan alam sekitar) dan mikrokosmos (bangunan dan penghuninya), tercermin dari bangunan yang ramah lingkungan dan iklim setempat dengan memperhatikan aspek temperatur, kelembaban udara, pergerakan udara, curah hujan dan radiasi matahari. 


\section{Sistem struktur dan konstruksi}

Aspek sistem struktur dan konstruksi bangunan arsitektur vernakular memiliki keunikan tersendiri, sesuai dengan potensi sumber daya alam dan masyarakat pada lingkungannya. Selanjutnya menurut Purwanto dan Gayatri (2007), hunian yang memiliki kekokohan struktural akan dapat meminimalisir kemungkinan terjadinya kecelakaan yang diakibatkan oleh adanya keruntuhan bangunan, sehingga sistem sambungan harus memiliki tingkat rigid yang baik, agar sistem rangka bangunan dapat bertahan dari goncangan yang diakibatkan oleh fenomena alam. Dari hasil riset Purwanto dan Gayatri (2007), bangunan tradisional suku Mee terbuat dari bahan kayu, yang diruncingkan dan ditancapkan di tanah. Kayu-kayu tersebut sebagai pemikul atap dan sekaligus berfungsi sebagai dinding, sedangkan sebagai pengikatnya digunakan tali rotan, selanjutnya bahan atap digunakan dari alang-alang. Untuk suku pendatang, yaitu suku Moni, berupa rumah panggung. Bahan bangunan yang dipilih mengikuti pertimbangan faktor ekonomi, efisiensi waktu dan sistem pengerjaannya.

\section{Pola permukiman arsitektur vernakular dalam konteks perkotaan}

Arsitektur vernakular merupakan pengembangan dari arsitektur rakyat yang memiliki nilai ekologis, arsitektonis dan alami karena mengacu pada kondisi alam, budaya dan masyarakat lingkungannya (Papanek 1995 dalam Amanati 2010). Selanjutnya permukiman arsitektur vernakular juga berorientasi pada lingkungan jalan perkotaan yang dibangun di sekitar lingkungan permukiman, sehingga aspek sosial ekonomi juga menjadi salah satu pertimbangan dalam pertumbuhan bangunan arsitektur vernakular yang berkelanjutan, sedangkan dengan memelihara keberlanjutan aspek sosial budaya seperti "an intangible heritage" akan dapat memberikan pengaruh percepatan reaksi pada aspek pengembangan arsitektur vernakular (Wardhani dan Moerdiartianto 2002).

\section{Simpulan}

Sketsa bentuk dasar asli salah satu rumah vernakular pesisir adalah seperti Gambar 8. Ditemukan dari hasil penelitian ini bahwa rumah tumbuh sehat sederhana pada hunian vernakular di area pesisir pantai Padang, Sumatra Barat, Indonesia. Perluasan ruang (Gambar 9) yang dilakukan adalah di bagian belakang dari masa bangunan utama dan memiliki bentuk empat persegi panjang dan memanjang ke arah belakang.

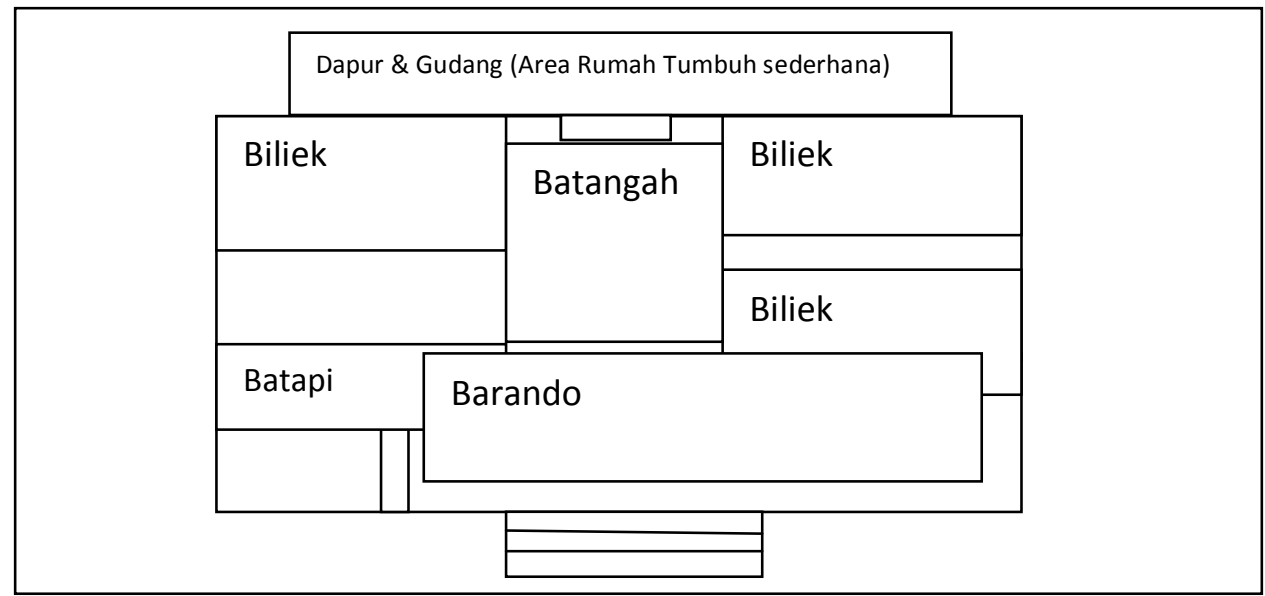

Gambar 8.

Sketsa tipologi denah rumah panggung 

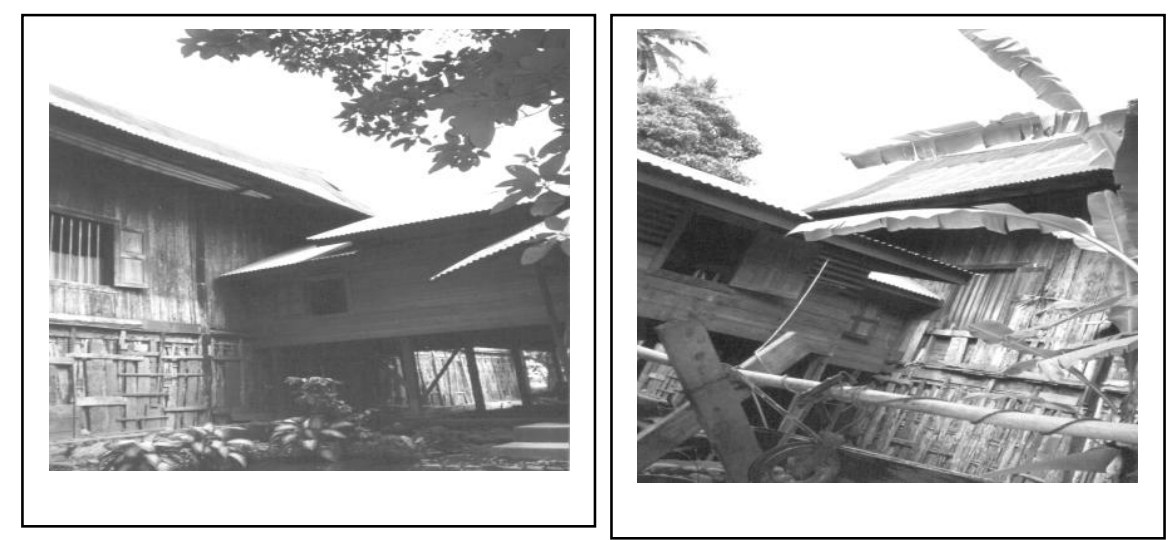

Gambar 9.

Rumah tumbuh dengan perluasan ruang ke arah belakang

Berikut adalah pengembangan konsep baru dari vernacular architecture pesisir pantai. Skematik model konsep baru vernakulararchitecture di Indonesia adalah seperti pada Skema 1.

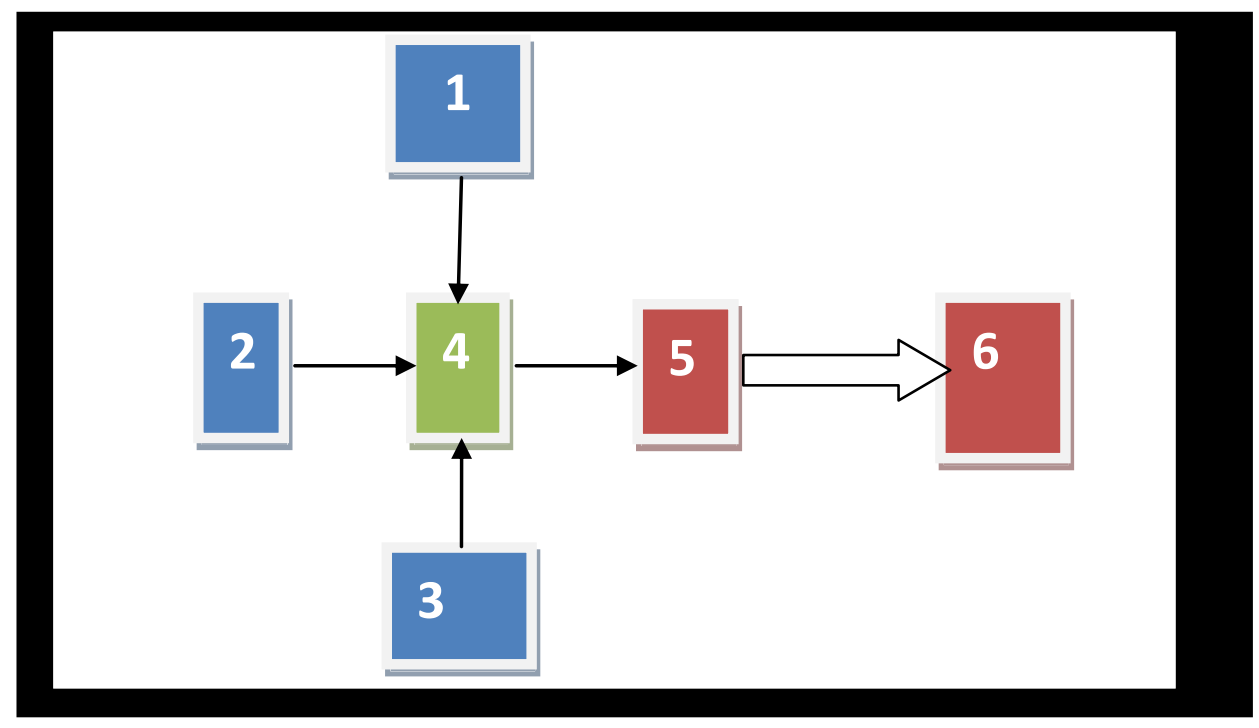

Skema 1.

Skematik model konsep baru vernacular architecture di Indonesia

Keterangan Skematik Model

\begin{tabular}{ll}
\hline & Keterangan \\
\hline 1 & Inspirasi dari Eksistensi Karakteristik Bangunan Vernakular Pesisir Pantai \\
2 & Inspirasi dari Karakteristik Eksistensi suatu Desa Kecil pada Kawasan Pesisir Pantai \\
3 & Potensi Material Modern \\
4 & Karakteristik Lokasi di Indonesia \\
5 & Intepretasi secara Terbuka dan Menyeluruh dari Kontekstual Aspek- Aspek \\
& Pertimbangan Rancang Bangun \\
6. & Transformasi bentuk baru \\
\hline
\end{tabular}

Dengan memperhatikan model konsep baru vernakular architecture di Indonesia akan dapat memperkaya alternatif desain/rancang bangun suatu karya lingkungan buatan/gedung yang berpijak dengan jati diri bumi Indonesia. Proses transformasi bentuk arsitektur dengan konsep baru vernakular di Indonesia antara lain dengan mempertimbangkan beberapa hal, meliputi 1) Inspirasi dari Eksistensi Karakteristik Bangunan Vernakular Pesisir Pantai, 2) Inspirasi dari Karakteristik 
Eksistensi suatu Desa Kecil pada Kawasan Pesisir Pantai, 3) Potensi Material Modern, dan 4) Karakteristik Lokasi di Indonesia

Selanjutnya dengan memperhatikan empat hal tersebut diatas maka dilakukan intepretasi secara terbuka dan menyeluruh dari kontekstual seluruh aspek pertimbangan dalam rancang bangun suatu hunian/gedung.

\section{Daftar Pustaka}

Amanati R (2010) Identifikasi tampilan visual arsitektur rumah tinggal vernakular di Bonjol Sumatera Barat. Jurnal Sains dan Teknologi 9(1):19-25.

Budihardjo E (1997) Arsitektur pembangunan dan konservasi. Jakarta: Penerbit Djambatan.

Ching FDK (1984) Arsitektur: bentuk ruang \& susunannya. Jakarta: Penerbit Erlangga.

Defiana A (2002); "Rumah Panggung" and it's thermal response to local climate (case study of Rumah Panggung Nias Utara); Proceeding Internasional Simposium; Buildng Research and the Sustainability of the Built Environment in the Tropics, Jakarta.

Nuryanto \& Machpudin I (2008) Kajian pola kampung dan rumah tinggal, Warga Kasepuhan Kesatuan Adat Banten Kidul di Sukabumi Selatan, Jawa Barat. Bandung: Universitas Pendidikan Indonesia.

Purwanto L \& Gayatri CS (2007) Arsitektur vernakular Nabire dan kondisi Nabire pasca gempa. Jurnal Dimensi Teknik Arsitektur 35(1):13-22.

Richardson V (2001) New vernakular architecture. London: Laurence King Publishing.

Wardhani AG \& Moerdiartianto (2002) Kampung Melayu Semarang: the development of vernakular architecture on the vision of urban management. Second International Seminar on Vernakular Settlement, Departement of Architecture, Faculty of Engineering University of Indonesia, Jakarta. 